\title{
The Effect of Index Futures Contracts on Indices in Futures Markets
}

\author{
Semra Taspunar Altuntas \\ Department of Finance \\ School of Business, Istanbul University \\ 34320, Istanbul, Turkey \\ E-mail: staspunar@istanbul.edu.tr
}

\begin{abstract}
:
The floating exchange rate system has caused both interest rate and exchange rate risk. This situation required companies to focus on risk management. Measuring and managing risk has come to the fore. At this point, the person responsible for the finance of a firm must know how to use the derivatives and how they will be priced. Today, the importance of futures markets is very huge. The period in which they affect the spot market may also change in the country-based period. The aim of the study from developing countries like Turkey, India, Brazil and China, to examine the impact of the spot market on futures markets. In this context, the daily closing values of the mentioned markets and the end-of-day settlement prices of the futures contracts are used. Stability of series was examined in country basis, and the appropriate delay lengths were determined by establishing VAR model. In addition, the existence of any long term relation has been examined by using the Johansen cointegration test and the status of the relationship is determined by applying the Granger causality test. As a result, it has been determined that in India and China, the future markets have a positive effect on spot market whereas in Turkey and Brazil they have no effect.
\end{abstract}

Keywords: Johansen Cointegration Test, Granger Causality, Futures market, Quantitive study, BIST30

DOI: $10.7176 / \mathrm{JSTR} / 5-2-29$

\section{Introduction}

Today, the beginning of the futures used for many purposes is based on the early years of the 19th century. Fluctuations in agricultural prices due to seasonality could put producers at risk. At the same time, difficulties in transportation of goods and inadequate warehouses could cause serious problems. In this period, producers and traders started to make commercial contracts between themselves. With the development of contracts, market participants increased. Investors as well as speculators are involved in the process. The Chicago Mercantile Exchange (CME) was established in 1919 with the growth of the markets.

Analyzes of futures and spot market interactions have been conducted for many years. As a result of the studies conducted in Turkey and abroad, different results have been reached based on country and underlying asset. Two types of analysis were applied in the studies. Volatility Analysis is the analysis of spot market volatility before and after the futures trading. In this analysis method, spot index data is used as the only independent variable. The data set has been turned into two different time series before and after the term of the futures market. The volatility of these two series was then investigated. The researchers who applied this analysis benefited from the Autoregressive Conditional Heteroskedasticity (ARCH) family models.

The Analysis of Causality (Preliminary-Consecutive) Relationship is the analysis to examine the direction and strength of the relationship between the futures and the spot data. Futures and spot data were analyzed as two independent variables. Researchers using this method of analysis generally conducted the longterm relationship (cointegration) between the series and the strength (effect-response) analysis of this relationship. The tests and models used are the Johansen cointegration and Granger causality tests, Vector Autoregressive (VAR) and Vector Error Correction (VEC) models.

\section{Theoritical Framework}

Interest futures contracts were started to be developed in 1976 with the removal of interest rate ceilings in the USA. With the floating exchange rate system, the fluctuation of money caused the exchange rate risk 
as well as the interest rate risk (Chambers, 2009). The first index futures contract was used in 1982 by Kansas City Board of Trade under the name Value Line Contract (Gülen, Mathew, 2000). With the transition to the electronic system in all the futures exchanges in the world, the records are kept on a regular basis. According to the data of The Bank of International Settlements (BIS), which holds these statistics worldwide, the financial futures and option contracts traded in organized exchanges in 1990 had a total transaction volume of 2.3 trillion USD. There is a contract of USD 9.3 trillion in 1995, USD 14.2 trillion in 2000 and USD 105.5 trillion in circulation in 2018.03 period (BIS, 2008).

In addition to futures and option contracts traded in organized exchanges, forward contracts, swap contracts, credit default swaps and option contracts are also known as over the counter (OTC) markets. According to the records of BIS, there was an agreement amounting to USD 72.1 trillion in the over-thecounter markets. This figure was USD 95.2 trillion in 2000, USD 299.3 trillion in 2005 and USD 531.7 trillion according to 2017 data.

Table 1. Trading volume of derivatives in Over the Counter Markets (Billion \$)

\begin{tabular}{|l|l|l|l|l|l|}
\hline & 2017 & 2016 & 2015 & 2014 & 2013 \\
\hline Interest & 426,649 & 385,514 & 395,138 & 519,607 & 600,821 \\
\hline Foreign exchange & 87,117 & 78,781 & 75,953 & 82,062 & 78,492 \\
\hline CDS & 9,354 & 9,931 & 12,379 & 16,507 & 21,142 \\
\hline Index and Stock & 6,570 & 6,253 & 7,241 & 7,096 & 6,705 \\
\hline Goods & 1,862 & 1,671 & 1,504 & 2,103 & 2,469 \\
\hline Other & 137 & 100 & 55 & 70 & 80 \\
\hline Total & 531,689 & 482,250 & 492,270 & 627,445 & 709,709 \\
\hline \multicolumn{7}{|c|}{ BIS, Statistics on OTC Derivatives } \\
\hline
\end{tabular}

Futures contracts in Turkey started to be traded in 2005 with the opening of VOB/VIOP. The analyzes started as of this period. The purpose of some studies in Turkey, data sets used, are summarized below, together with the test-models applied and results achieved.

Özen investigated the effect of futures on spot market efficiency in his study in 2008. As a data, spot and daily closing prices of BIST30 index were used between 01.01.2003 and 30.04.2007 and Engle Granger cointegration test and error correction model were used as model. In the study, the effect of the futures market on the spot market was expected. As a result of the study, it was concluded that the futures market did not contribute positively to the spot market; on the contrary, the spot market had an effect on the futures market.

Kayalıdere, Arıcı and Aktaş (2012) analyzed the interaction between spot and futures markets in their study. As a data, between the dates of 02.01.2006 - 30.12.2011, ISE30 and USD / TL, spot and futures contracts were used. Granger causality test, VAR and VEC were used as models. The data were divided into two periods as 2006-2008 and 2008-2011. In the first period, it was concluded that the spot market had an interaction with the futures market and in the second period the futures market showed an interaction with the spot market.

In a study that investigated the pre-succession relationship between spot and futures markets, the period $02.2005-12.2010$ was taken as the data (Özdemir, 2011). Johansen cointegration and Granger causality test were used. As a result of the study, long-term relationship between the two markets was determined. However, it was found that the futures market did not lead to the spot market.

Odabaşı conducted a research in 2014 and explored the interaction between spot and futures market in a multifaceted way. As a data, end of day closing values of futures contracts based on BIST30 index and BIST30 were used between 02.01.2001 and 30.06.2013, while Johansen cointegration and Granger causality test, VAR, VEC models and ARCH family models were applied. As a result of the study, it was found that the volatility of the spot index fell and the interaction between the index futures and the spot market were stronger on the futures market.

Özer and Çömlekçi (2015) investigated how spot market volatility is affected after 2005, when VOB was founded. As a data, the daily closing values of BIST 100 spot index between 1997 and 2015 were used as ARCH. As a result of the study, it was concluded that spot market volatility decreased in the post-2005 period and that there was a negative relationship between the futures market and the spot market.

In a study conducted in 2016, the causality (premise-successor) relationship between futures and spot market was investigated (İşeri, Kaçmazer, 2016). The daily closing prices of the BİST30 and BİST30 
futures contracts were used between 04.02.2005 and 15.09.2015, and the model was analyzed by Johansen cointegration and Granger causality test, VEC model, variance decomposition and impact response analyzes. As a result of the study, it is concluded that the causality relation is accurate from the spot market.

İşeri and Kaçmazer (2017) investigated the effect of futures markets on spot market volatility. BİST30 spot and futures daily prices were used between 22.06.2011 - 15.09.2015 and ARCH was used as a model. Since the transactions in VIOP started in 2013, spot and futures index data were divided into two parts as 2011-2013 and 2013-2015. In the study, it was concluded that the futures market decreased volatility in the spot market with the beginning of VIOP in 2013.

As a result of volatility analysis carried out in Turkey, after the beginning of futures volume on the market, it has been found to decrease the volatility of the spot market. As a result of the causality analysis, it was determined that spot market affected futures market.

Chiang and Wang (2002) examined the effect of index futures contracts on spot market volatility in Taiwan. Stock exchange of Thailand (TSE) spot data was used between 1995-2000 and divided into three separate time series. ARCH family models were used as models. As a result of the study, it was observed that spot market volatility increased with the beginning of index futures contracts.

Bae, Kwon and Park (2004) investigated the effect of index futures contracts on spot market volatility. The Korea Composite Stock Price Index 200 (KOPSI200) spot index was divided into separate time periods between 1990-1998. As a result of the study, it was found that spot index volatility increased with the beginning of index futures contracts.

In a study conducted in Greece, the spot data for the impact of the futures market on spot market volatility was divided into two time series between 1997-2004. These two series are examined with the ARCH family models (Alexakis, 2007). In the study, it was concluded that the initiation of futures contracts did not have a significant effect on spot market volatility.

In South Africa, the study examined the causality and volatility analysis between futures and spot market (Floros, 2009). FTSE Johannesburg Stock Exhange (FTSE / JSE) was used as the first 40 spot and futures index closing prices. Johansen Cointegration and Granger causality tests and VECM and ARCH family models were used as models. As a result of the study, it was found that the futures and spot markets are in long-term relationship and the futures market is affecting the spot market.

In the study conducted in Ukraine, spot market volatility was examined with the beginning of futures markets in Russia, Poland, Czech Republic, Romania and Ukraine (M.Milovanova, 2013). In Russia, spot index data of the RTS index between 1995 and 1999 were used. In Poland the WIG20 index was used between 1995-2000, Czech Republic PX index between 2002-2010, for Romania BET index between 2003-2011 and for Ukraine UX index between 2008-2013. In the study, it was concluded that spot index volatility increased in Russia and Poland, decreased in Ukraine and no significant change in Czech Republic and Romania.

In India, the causality between the market and spot market was investigated (Pradhan, 2017). Spot and futures closing prices of S\&P CNX Nifty index between 2000-2016 were taken and ARIMA and VEC models were applied as model. As a result of the study, it was found that there was a long-term relationship between futures and spot market and the direction of the relationship was from spot to futures. Although there are changes in country-based studies in developing countries, differences can be seen in different countries such as our country. For this reason, generalization over the results will not be a realistic result.

\section{Research Method}

In the analysis, BIST30 is used for Turkey, S\&P CNX Nifty is used for India, FTSE China A50 is used for China and Bovespa is used for Brasil. Daily closing values of the stock exchanges between the dates 03.02.2014 - 21.09.2018 and the day-end settlement prices of the futures contracts were taken. In practice, the steps are given:

1- Stability - Stability of the series to be used in the model will be investigated by Augmented Dicker Fuller (ADF) and Phillips-Perron (PP) unit root tests, if not, it will be tried to stabilize by taking primary or secondary differences of series.

2- Determination of Appropriate Delay Length - VAR model will be established and the delay length will be determined.

3- Cointegration - Johansen Cointegration test will be applied to prove the existence of long term relationship between the series.

4- Causality: The direction of the relationship will be determined by Granger Causality Test. In statistical methods applied with all time series including financial time series, it is assumed that the series are stationary. 
Although there are many methods to show the stability of the series, ADF and PP unit root tests are applied in this study.

\section{Findings}

In the analyzes conducted with non-stationary series, supurious regression may occur and realist results cannot be obtained. Therefore, in order to stabilize the series, stability tests are performed by taking the differences. ADF and PP unit root tests are applied. When each series is examined separately according to $\mathrm{ADF}$ and $\mathrm{PP}$ tests, the hypothesis $\mathrm{H}_{0}$ is rejected in all countries because the t-statistic values are smaller than all of the critical values. As a result, when the difference of each series is taken, it is understood that the series do not contain unit roots. If we examine the ADF test of the BIST30 spot price time series, the t-statistic value is -1.81 is greater than the critical value of $-3.43(1 \%)$, the critical value of $-2.86(2 \%)$ and the critical value $-2.56(10 \%)$. Since each series is examined separately according to ADF and PP tests, it is understood that the t-statistic values are greater than at least one of the critical values that are found just below, so it is understood that each series has unit root in the level values, in other word it is not stationary. In the analyzes conducted with non-stationary series, spurious regression may occur and healthy results cannot be obtained. For this reason tests are performed to make the series stationary and stationary tests are performed. When each series is examined separately according to ADF and PP tests, it is understood that when the 1st digit of each series is taken as the t-statistic values are smaller than all of the critical values below it, the series do not have unit roots, ie they are stationary.

The Johansen cointegration test is used to investigate the existence of a long-term relationship between the series. In this context, VAR model has been established for each country's spot and future price series and lag lengths have been found. One of the methods used to determine the delay length is information criteria. Delay length of 2 have been selected for Turkey, India and China and also 1 is for Brazil. Johansen cointegration tests were applied according to the number of delay to analyze hypotheses:

Table 2. Johansen Cointegration Test Results

\begin{tabular}{|c|c|c|c|c|}
\hline \multicolumn{3}{|c|}{ Series: TR S TR F } & & \\
\hline \multicolumn{5}{|c|}{ Lags internal (in first differences): 1 to 2} \\
\hline Hypothesized & & Trace & 0.05 & \\
\hline No. Of CE(s) & Eigenvalue & Statistic & Critical Value & Prob.** \\
\hline None* & 0.03340938 & 44.297153 & 15.49471 & 0.0000 \\
\hline At most 1 & 0.00212012 & 2.6036971 & 3.841466 & 0.10691 \\
\hline Hypothesized & & Max-Eigen & 0.05 & \\
\hline No. Of CE(s) & Eigenvalue & Statistic & Critical Value & Prob.** \\
\hline None ${ }^{*}$ & 0.03340938 & 41.693462 & 14.2646 & 0.0000 \\
\hline At most 1 & 0.00212012 & 2.6036971 & 3.841466 & 0.10691 \\
\hline \multicolumn{5}{|c|}{ Series: CH S CH F } \\
\hline \multicolumn{5}{|c|}{ Lags internal (in first differences): 1 to 2} \\
\hline Hypothesized & & Trace & 0.05 & \\
\hline No. Of CE(s) & Eigenvalue & Statistic & Critical Value & Prob. ${ }^{* *}$ \\
\hline None * & 0.08020913 & 106.6055 & 15.49471 & 0.0001 \\
\hline At most 1 & 0.00327227 & 4.0212102 & 3.841466 & 0.0450 \\
\hline Hypothesized & & Max-Eigen & 0.05 & \\
\hline No. Of CE(s) & Eigenvalue & Statistic & Critical Value & Prob.** \\
\hline None* & 0.08020913 & 102.58428 & 14.2646 & 0.0000 \\
\hline At most 1 & 0.00327227 & 4.0212102 & 3.841466 & 0.0450 \\
\hline
\end{tabular}




\begin{tabular}{|c|c|c|c|c|}
\hline Series: IN S IN & & & & \\
\hline Lags internal (i & erences): 1 to & & & \\
\hline Hypothesized & & Trace & 0.05 & \\
\hline No. Of CE(s) & Eigenvalue & Statistic & Critical Value & Prob.** \\
\hline None* & 0.0879839 & 115.85404 & 15.49471 & 0.0001 \\
\hline At most 1 & 0.00232532 & 2.8562344 & 3.841466 & 0.0913 \\
\hline Hypothesized & & Max-Eigen & 0.05 & \\
\hline No. Of CE(s) & Eigenvalue & Statistic & Critical Value & Prob.** \\
\hline None* & 0.0879839 & 112.99778 & 14.2646 & 0.0000 \\
\hline At most 1 & 0.00232532 & 2.8562344 & 3.841466 & 0.0913 \\
\hline Series: BR S BR & & & & \\
\hline Lags internal (i & rences): 1 to & & & \\
\hline Hypothesized & & Trace & 0.05 & \\
\hline No. Of CE(s) & Eigenvalue & Statistic & Critical Value & Prob.** \\
\hline None * & 0.06223818 & 70.886035 & 15.49471 & 0.0000 \\
\hline At most 1 & 0.00143844 & 1.5527762 & 3.841466 & 0.2132 \\
\hline Hypothesized & & Max-Eigen & 0.05 & \\
\hline No. Of $\mathrm{CE}(\mathrm{s})$ & Eigenvalue & Statistic & Critical Value & Prob.** \\
\hline None * & 0.06223818 & 69.333254 & 14.2646 & 0.0000 \\
\hline At most 1 & 0.00143844 & 1.5527762 & 3.841466 & 0.2132 \\
\hline
\end{tabular}

Because of the Trace Statistic 44.2972 value for Turkey, which is greater than the critical value 15.49 and also, the Max-Eigen Statistic value is greater thanthe critical value 14.2646, the $\mathrm{H}_{0}$ hypothesis is rejected. Since similar situation exists in other countries, there is no cointegrated vector hypothesis between spot and forward price series of all countries included in the study. In the last part of the study, it is investigated that the spot and forward price series in countries with long-term relations are affected by each other. In this context, Granger causality test is applied over VEC model. The results of the Granger causality tests are given in the table.

Table 3. Granger Causality Test Results

\begin{tabular}{|c|c|c|c|c|c|c|c|}
\hline \multicolumn{4}{|c|}{ Dependent Variable: D(TRSpot) } & \multicolumn{4}{|c|}{ Dependent Variable: D(INSpot) } \\
\hline Excluded & Chi-sq & $\mathrm{df}$ & Prob. & Excluded & Chi-sq & df & Prob. \\
\hline $\mathrm{D}$ (TRFutures) & 5.413644 & 2 & 0.0669 & $\mathrm{D}$ (INFutures) & 7.951512 & 2 & 0.0188 \\
\hline All & 5.413644 & 2 & 0.0669 & All & 7.951512 & 2 & 0.0188 \\
\hline \multicolumn{4}{|c|}{ Dependent Variable: $\mathrm{D}$ (TRFutures) } & \multicolumn{4}{|c|}{ Dependent Variable: D(INFutures) } \\
\hline Excluded & Chi-sq & df & Prob. & Excluded & Chi-sq & df & Prob. \\
\hline $\mathrm{D}$ (TRSpot) & 10.40918 & 2 & 0.0055 & $\mathrm{D}$ (INSpot) & 3.747161 & 2 & 0.1541 \\
\hline All & 10.40918 & 2 & 0.0055 & All & 3.747161 & 2 & 0.1541 \\
\hline \multicolumn{4}{|c|}{ Dependent Variable: D(BRSpot) } & \multicolumn{4}{|c|}{ Dependent Variable: D(CHSpot) } \\
\hline Excluded & Chi-sq & df & Prob. & Excluded & Chi-sq & df & Prob. \\
\hline D(BRFutures) & 1.55324 & 1 & 0.2131 & $\mathrm{D}$ (CHFutures) & 6.131809 & 2 & 0.0469 \\
\hline All & 1.55324 & 1 & 0.2131 & All & 6.131809 & 2 & 0.0469 \\
\hline \multicolumn{4}{|c|}{ Dependent Variable: D(BRFutures) } & \multicolumn{4}{|c|}{ Dependent Variable: D(CHFutures) } \\
\hline Excluded & Chi-sq & $\mathrm{df}$ & Prob. & Excluded & Chi-sq & df & Prob. \\
\hline $\mathrm{D}$ (BRSpot) & 0.697764 & 1 & 0.404204 & $\mathrm{D}$ (CHSpot) & 19.27571 & 2 & 0.0001 \\
\hline All & 0.697764 & 1 & 0.404204 & All & 19.27571 & 2 & 0.0001 \\
\hline
\end{tabular}

In the Granger causality test tables, the dependent variable is expected to be affected. Just below the argument is the variable that is expected to affect. If the probability value is below $0.05, \mathrm{H}_{0}$ hypothesis is rejected. That is, the dependent variable is interpreted to be affected by the argument. If we look at the values on the basis of countries;

In Turkey, when TRSpot is the dependent variable, TRForward represents the probability value was 0.0669. That was greater than 0.05. This shows that the forward index prices of BIST30 do not affect BIST30 spot index prices. While TRForward is a dependent variable, the probability value of TRSpot is 0.0055, which is less than 0.05. In China, when CHSpot is the dependent variable, CHForward represents the probability value was 0.0469 . That was less than 0.05 . This shows that the forward index prices affects spot index prices. While CHForward is a dependent variable, the probability value of CHSpot is 0.0001 , which is less than 0.05. This shows that FTSE China A50 spot index prices have an impact on FTSE China 
A50 futures index prices. In India, when INSpot is the dependent variable, INForward represents the probability value was 0.0188 . That was less than 0.05 . This shows that the forward index prices affects spot index prices. While INForward is a dependent variable, the probability value of INSpot is 0.1541 , which is more than 0.05 . This shows that S\&P CNX Nifty spot index prices do not affect futures index prices. In Brazil, when BRSpot is the dependent variable, BRForward represents the probability value was 0.2131 . That was more than 0.05 . This shows that the forward index prices do not affect spot index prices. While BRForward is a dependent variable, the probability value of BRSpot is 0.4042 , which is more than 0.05. This shows that Bovespa spot index prices do not affect futures index prices.

Our basic hypotheses, while valid in Turkey and Brazil, are rejected in India and China within the scope of the test results. In summary, futures market in Turkey and Brazil does not effect the spot market; but in India and China, the futures market is affecting the spot market.

\section{Conclusion and Discussion}

In this study, the impact on the spot index value of index futures contracts traded in China, Turkey, India, Brazil, which are developing countries, were investigated. Firstly, stability was analyzed in the analysis of price series and appropriate delay length was determined. After that, the cointegration test was applied and the causality direction was determined. The effect of participants who invest in futures markets only with the return appetite created by leveraged transactions; low trading volume of futures markets compared to the spot market; the effect of participants who invest in the spot market but do not take the possibility of falling profitability and hedging the portfolios and not taking a reverse position in the futures market, are the possible reasons why futures are not affecting the spot market.

Index futures contracts should be able to give information about the future direction of the stock market index subject to the underlying asset. We can summarize the expectation of the causality direction from the futures market to the spot market as follows: Low costs in futures market; leverage effect to generate higher returns in the market news; and also it is not possible to trade in the whole of the index in spot market, so it is possible in the futures market and thus it can provide protection.

Indexes reflect the movements of the shares they represent. Especially the changes in the index give information about the course of the economy. By comparing the index futures price with the spot index value, forecasts can be made about the future direction of the country's economy. For this reason, suggestions are given below to ensure that futures markets have an impact on the spot market and increase the effectiveness of the futures market: Tax advantages can be provided to increase the market efficiency of lawmakers; operations that can be determined for protection purposes can be made attractive; differences between derivative products and credit derivatives can be explained to the market despite the concern about the derivative product in the market; it can be explained that the cost can be fixed by providing a cost link with the derivative transaction in the hedging transactions, the damage that may occur due to the derivative product is not important after the process is connected and the cost fixation is the most important one.

\section{References}

Alexakis, P. (2007). On The Effect Of Index Futures Trading On Stock Market Volatility, International Research Journal of Finance and Economics, Issue 11.

Bae, S. C., Kwon, T. H., \& Park, J. W. (2004). Futures Trading, Spot Market Volatility, And Market Efficiency: The Case Of The Korean Index Future Markets, The Journal of Future Markets, Volume 24. Issue 12

BIS. [Online]. http://stats.bis.org/statx/toc/DER.html

CBOE. [Online]. http://www.cboe.com/aboutcboe/History.aspx

Chambers, N. (2009). Türev Piyasalar, Beta Basım Yayım A.Ş.

Chiang, M.-H., \& Wang, C.-Y. (2002). The Impact Of Futures Trading On Spot Index Volatility: Evidence For Taiwan Index Futures, Taylor \& Francis Journals, Issue 9.

Floros, C. (2009). Price Discovery In The South African Stock Index Futures Market. International Research Journal of Finance and Economics, Say1 34. 
Gülen, H., \& Mayhew, S. (2000). Stock Index Futures Trading And Volatility In International Equity Markets, The Journal Of Futures Markets, Volume 20. Issue 7.

İşeri, M., \& Kaçmazer, M. (2016). 2005-2015 Yılları Arasında BİST30 Endeksi Ve BİST30 Endeks Vadeli İşlem Sözleşmeleri Arasındaki Nedensellik (Öncül-Ardıl) İlişkisinin İrdelenmesi, Finans Politik ve Ekonomik Yorumlar, Cilt 53. Say1 615.

İşeri, M., \& Kaçmazer, M. (2017). 2011-2015 Yılları Arasında BİST 30 Endeksi ve BİST 30 Endeks Vadeli İşlem Sözleşmeleri Arasındaki Volatilite İlişkisinin İrdelenmesi, Marmara Üniversitesi Iktisadi ve İdari Bilimler Dergisi, Cilt 39. Sayı 1.

Kayalıdere, K., Arıcı, H., \& Aktaş, H. (2012). Türev Ve Spot Piyasalar Arasındaki Etkileşim: VOB Üzerine Bir İnceleme, Muhasebe Ve Finansman Dergisi, Ekim.

Milovanova, M. (2013). Index Futures Trading And Stock Market Volatility: Evidence From Several Eastern European Countries.

Odabaşı, S. (2014). Endeks Vadeli İşlem Sözleşmeleri İle Spot Piyasa Arasındaki Etkileşimlerin İrdelenmesine Yönelik BİST30 Üzerinde Bir Çalışma.

Özdemir, L. (2011). Vadeli İşlem Piyasası İle Spot Piyasa Oynaklığı Arasındaki İlişki: İzmir Vadeli İşlem ve Opsiyon Borsası Üzerine Bir Uygulama, Yayınlanmış Doktora Tezi.

Özen, E. (2008). İzmir Vadeli İşlem ve Opsiyon Borsası'nda Hisse Senedine Dayalı Futures İşlemlerinin Spot Piyasaya Etkinliğinin Katkısı: İMKB 30 Endeksi İçin Bir Uygulama. Doktora Tezi.

Özer, A., \& Çömlekçi, İ. (2015). Vadeli Ve Spot Piyasalar Arasındaki Etkileşim: VOB Üzerine Bir Uygulama, Bartın Üniversitesi İ.I.B.F. Dergisi, Cilt 6. Sayı 12.

Pradhan, K. C. (2011). The Hedging Effectiveness of Stock Index Futures: Evidence for the S\&P CNX Nifty Index Traded in India, National Council of Applied Economic Research, Volume 6. Issue 1. 